\title{
First record of the Asian diaptomid Neodiaptomus schmackeri (Poppe \& Richard, 1892) (Crustacea: Copepoda: Calanoida) in Europe
}

\author{
Giuseppe ALFONSO, ${ }^{*}$ Riccardo RUSSO, Genuario BELMONTE \\ Laboratorio di Zoogeografia e Fauna, Dipartimento di Scienze e Tecnologie Biologiche e Ambientali (Di.S.Te.B.A.), Università del \\ Salento, via Monteroni campus Ecotekne, 73100 Lecce, Italy \\ *Corresponding author: giuseppe.alfonso@unisalento.it
}

\begin{abstract}
Albania, as well as a great part of the Balkan area in general, still suffers a lack of environmental studies especially in limnological research. The Dumre plateau, in Central Albania, is characterized by an extraordinary high number of karst lakes in a small geographic area. Despite their environmental peculiarity, very few biological data are to date available for these lakes, none on the zooplankton. For this reason, 15 water bodies located in the central area of the plateau were selected for a preliminary limnological survey carried out in the years 2008-2011. Neodiaptomus schmackeri (Poppe \& Richard, 1892), a diaptomid calanoid copepod characterized by a South-Eastern Palearctic - Oriental distribution, and the most widely spread Neodiaptomus species in Asia, was found in 8 lakes of the Dumre area. This finding represents the first record of the species, and of the entire genus Neodiaptomus, for Europe. Several environmental variables were measured to characterize the lakes, and the co-occurring planktonic crustaceans were also identified. Taxonomical drawings and descriptions of the main morphological features of both sexes are herein provided in order to compare the Albanian populations of $\mathrm{N}$. schmackeri with those of the native distribution area of the species. The possible causes which determined the occurrence of this non-indigenous species in several Dumre lakes are discussed.
\end{abstract}

Key words: Zooplankton, karst lakes, Albania, Dumre plateau, biogeography, non-indigenous species.

Received: March 2014. Accepted: May 2014.

\section{INTRODUCTION}

The findings of non-indigenous species in the inland waters are occurrences that have been increasingly documented in the last few decades (at least since the 1980s onwards), and mainly relate to man activities (i.e., recreation, fishery, aquaculture, trade) at global scale (Gherardi, 2007). Among Calanoida (Crustacea Copepoda), two nonindigenous extra-continental species have been reported in European inland waters to date. Boeckella triarticulata (Thomson, 1883) was reported for the first time in Europe in Northern Italy, where it arrived from the Australasian area most likely with live fish for aquaculture (Ferrari et al., 1991; Ferrari and Rossetti, 2006). The species then spread in the southern part of the Italian peninsula, especially in the newly built man-made reservoirs (Alfonso and Belmonte, 2008). The Nearctic diaptomid Skistodiaptomus pallidus (Herrick, 1879) has been recently reported for the first time in Europe (in Northern Germany) as being introduced via the ballast waters of ships arriving in the port of Bremen (Brandorff, 2011). Differently from the two extra-continental species, Eudiaptomus gracilis (Sars, 1862) is considered a case of intra-continental invader in Europe where it is currently in expansion southwards (Rossetti et al., 1996). It is a Palaearctic species, reported also in the United States (including Alaska) by Dussart and Defaye (2002), and one of the most widely spread calanoid in the European inland waters (Kiefer, 1978); however, it is quite rare throughout the circumMediterranean area (Rossetti et al., 1996). The invasion of E. gracilis in Italian lakes, where it was previously not present, has been favoured by the increased eutrophic conditions of lakes, and in several cases it determined the displacing of native species (Rossetti et al., 1996; Riccardi and Giussani, 2007; Riccardi and Rossetti, 2007; Visconti and Manca, 2010).

According to Dussart and Defaye (2002) and to the most updated literature, no species belonging to genus Neodiaptomus Kiefer, 1932 has ever been reported for the European inland waters. At least 14 species belonging to the genus Neodiaptomus are reported in the World Copepoda online database (Walter, 2013), although Ranga Reddy (2013) recently has critically recognised only 6 valid species for this genus. In any case, all the Neodiaptomus species currently known are distributed in Southern, South-Eastern and Eastern Asia (Borutzky, 1991, Roy, 1999; Dang and Ho, 2001; Dussart and Defaye, 2002; Sanoamuang and Athibai, 2002; Proongkiat and Sanoamuang, 2008; Ranga Reddy, 2013). Among them, Neodiaptomus schmackeri (Poppe and Richard, 1892) is the most widely distributed species being reported from Southern China, Nepal, Malaysia, Singapore, Bangladesh, India, Sri Lanka, Thailand, Philippines, Korea, Eastern 
Russia (Dussart and Defaye, 2002 and reference therein), Japan (Semura et al., 1986), and Taiwan (Young and Shih, 2011). N. schmackeri is the type species of the genus Neodiaptomus (Ranga Reddy and Subba Reddy, 1992; Ranga Reddy 1994; Dussart and Defaye, 2002).

To date, 9 species of Calanoida are known for Albanian inland waters: one belonging to the genus Mixodiaptomus (Shehu et al., 2009), four to the genus Arctodiaptomus and four to Eudiaptomus (Dhora, 2010). In the present paper we have reported the occurrence of Neodiaptomus schmackeri (Poppe and Richard, 1892) for the first time in Europe, as we collected this species in several lakes of central Albania. Taxonomical drawings and descriptions of the main morphological features of both sexes of the Albanian populations of $N$. schmackeri are provided in order to allow comparisons with populations from the native distribution area of the species. The possible causes of the species' occurrence in lakes very far from the native area of distribution are also discussed.

\section{METHODS}

\section{Study area: the Dumre plateau}

The Dumre area is a plateau (average altitude $175 \mathrm{~m}$ asl) of about 25,000 ha located in the Central Albanian district of Elbasan (Fig. 1C). The landscape is characterized by several exokarstic landforms (rocks are carbonates and evaporites of Permian-Triassic origin) represented mainly by dolines, and most of them are flooded with rainwater (the average annual rainfall is around $1060 \mathrm{~mm}$ in the

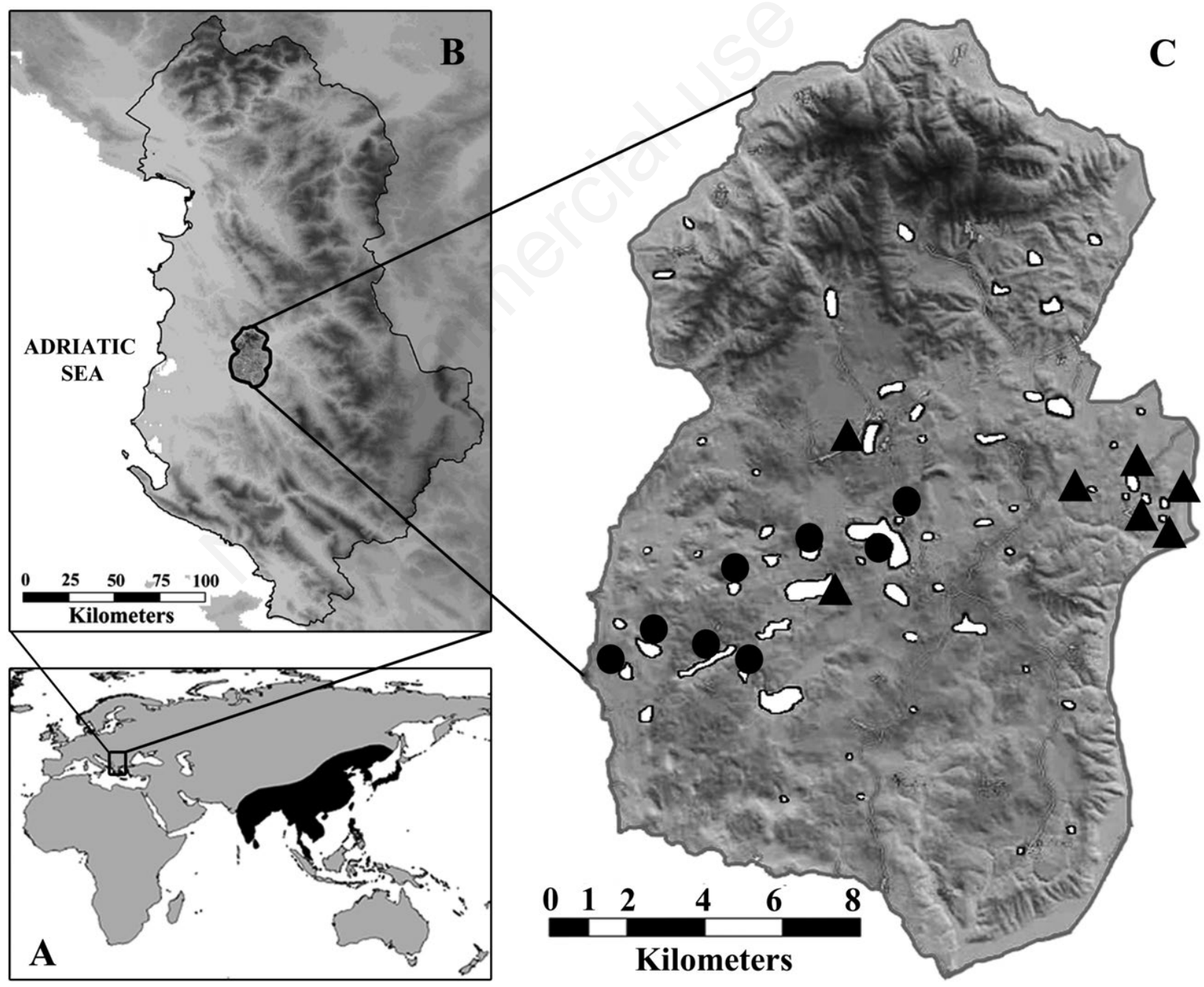

Fig. 1. A) Native distribution area of Neodiaptomus schmackeri. B) Map of Albania with detail of the Dumre area. C) The Dumre area with all lakes white coloured (lakes with a diameter lower than $150 \mathrm{~m}$ are not detectable at this scale); black dots represent the lakes with $N$. schmackeri, black triangles indicate the lakes without the species (map source of 1C is http://www.ekby.gr, modified). 
area) (Parise et al., 2008). As a consequence, the Dumre plateau hosts about a hundred karst lakes (Cullaj et al., 2005; Parise et al., 2008) most of which are small, generally less than 10 ha in surface-area and less than 20 meters deep. Despite the old pasture traditions, after the 1950s the land use in the Dumre area changed toward agriculture. The landscape has been then progressively deforested and transformed to cropland (Cullaj et al., 2005); at the same time an extensive use of pesticides and herbicides became to compromise the water quality of most of the lakes (Parise et al., 2008). Furthermore the water from the lakes was exploited for irrigation without any restriction causing damaging effects on the biota (Qiriazi and Sala, 2000).

In the 1960s, non native fish species from Asia were introduced in some water bodies (Peja et al., 2002), as a consequence of the close socio-economic relationships between Albania and China. In those years, Chinese technicians built several aquaculture facilities in Albania (Cobani, 2010), and several of them were located in the Dumre lakes, mainly for the breeding of cyprinid species (e.g. common carp and Chinese carps). Furthermore, the white Amur bream (Parabramis pekinensis (Basilewsky, 1855)), the black Amur bream (Megalobrama terminalis Richardson, 1846), the Wuchang bream (Megalobrama amblycephala Yih, 1955), and the stone moroko (Pseudorasbora parva Temminck and Schlegels, 1825) were also introduced in Albania from Asia in the same period (Peja et al., 2002; Shumka et al., 2008; Dhora, 2010; Hanel et al., 2011).

Pristine lacustrine ecosystems have suffered both these physical and biological stresses and thus many species, mostly native fishes, disappeared (Qiriazi and Sala, 2000). Currently there is no study or data on crustacean zooplankton in the Dumre lakes, therefore the possible effects of these impacts on the native zooplankton communities are completely unknown at present.

\section{Surveys and data collection}

Among the Dumre lakes, 15 were selected in the central area of the region for the limnological surveys.

Each lake was sampled at least once from September 2008 to June 2011 (Supplementary Tab. 1). Quantitative zooplankton samples were gathered in the whole water column (in correspondence of the maximum depth point) and in the euphotic zone only of the deepest lakes (those deeper than $5 \mathrm{~m}$ ). Two plankton nets (mouth $24 \mathrm{~cm}$, mesh size 200 and $50 \mu \mathrm{m}$ respectively), equipped with a flow-meter, were used in order to collect a larger size spectrum of zooplankton. When the same taxon was collected with both nets, only the higher abundance (i.e., that related to the most efficient net) was considered for the density evaluation. Samples were fixed in situ with buffered $(\mathrm{pH} 7.3)$ formalin (4\% of final concentration) or in ethanol (96\%). At least two sample replicates were collected in each lake per date with each net. Some environmental variables [temperature, $\mathrm{pH}$, conductivity and photosynthetically active radiation (PAR)] were measured using a multiprobe in each sampling station; depth was measured by an echo sounder. Geographical coordinates and altitudes were detected with a GPS and by studying maps. The surface area of the lakes was measured using the detailed aerial pictures available and the references of coastlines measured during the surveys. The Secchi Disk values were also registered during the samplings. Copepod species have been identified according to Bauer (1987), Boxshall and Halsey (2004), Dussart and Defaye (2001), Einsle (1993), Mirabdullayev and Defaye (2002), Ranga Reddy (1994). Branchiopod crustaceans were identified according to Alonso (1996) and Margaritora (1985). Taxonomic drawings based on the specimens of Neodiaptomus schmackeri collected in the lakes of Dumre have been realized under a compound microscope equipped with a camera lucida. Body sizes of both sexes were measured from the head to furcal rami (excluding furcal setae) with a micrometric glass.

About one hundred specimens ( $\sim 50$ females and $\sim 50$ males) collected at the Lake Pernaska on 10 September 2008 have been deposited in the collection of the Smithsonian Institution (National Museum of Natural History) in Washington DC with the catalogue number USNM \#1233790, courtesy of Dr. Chad Walter.

\section{RESULTS}

Neodiaptomus schmackeri (Poppe \& Richard, 1892) was found in eight lakes out of the 15 visited in the Dumre area (Fig. 1C; Tab. 1); the species was observed in all the dates in which these lakes were visited (Tab. 2). In lake Dega, sampled in four different dates, abundances were always in the range comprised between $10^{3}$ and $10^{4}$ individuals $\mathrm{m}^{-3}$, and the species was dominant on the whole zooplankton community in September 2008. Similarly, in lakes Pernaska, I Kuq and Dorbi N. schmackeri was dominant, in terms of abundance, on the zooplankton in the same date. The zooplankton assemblages of the lakes hosting $N$. schmackeri were mainly characterized by the cladocerans Bosmina longirostris (7 lakes) and Diaphanosoma brachyurum (6 lakes). The cyclopoid copepods Acanthocyclops trajani and Cyclops vicinus were detected in half of the lakes. Three cyclopoid taxa (two Ergasilidae and one Lernaeide) parasitic of fishes were also found (Tab. 2).

The environmental variables, recorded in each sampling date (Supplementary Tab. 1), show $\mathrm{pH}$ values (7.809.06) typical of alkaline waters. Most of the 15 visited lakes appeared holomictic because of their depths (from very shallow to moderately deep), with at least one mixing season during the year. The measured thermocline depth 
ranged from 2.69 to $7.84 \mathrm{~m}$ (during the spring and summer sampling) for those lakes in which the thermocline was present (see Supplementary Tab. 1 for details). Electric conductivity values ranged from 190 to $530 \mu \mathrm{S} / \mathrm{cm}$ considering all the dates in which lakes were sampled. The main morphological features of specimens collected in the Dumre area have been analyzed and drawn (Fig. 2). Female (Fig. 2A) is larger than male (Fig. 2B), being the average body size $1253 \pm 56 \mu \mathrm{m}(\mathrm{n}=89)$ and $1119 \pm 38$ $(n=118)$ respectively. Female antennules are longer than body-size and furcal setae (Fig. 2A). Fourth and fifth thoracic segments are fused, the latter is asymmetrical. Genital somite with asymmetrical lateral lobes bearing one spine on both right and left sides (Fig. 2C), protruding digitiform or spiniform processes in variable number only on the right side and above the spine (Fig. 2 C,D). Female fifth leg (Fig. 2E) slightly asymmetrical with strong cuneiform processes on the coxa, first exopodal article with a chitinous pillow on the inner side and a long seta on the outer side, second exopodal article with end claws equipped by strong denticles (number of denticles on the left claw is higher than in the right), and an outer small denticle only on the left claw.

Male urosome asymmetrical (Fig. 2F), with an hirsute ornamentation on both second and third urosomites visible only in lateral view (Fig. 2G). The right furcal ramus bears a digitiform process distally on the ventral side (Fig. 2H). Fifth pair of legs (Fig. 2I) characterized by a distal inner process on the right coxa ending with two lobes. Second right exopodal article lengthened, with the outer lateral spine in medial position and a sickle-like terminal claw. Right endopodite is proximally enlarged. Male right antennula (Fig. 2L) with a small spine on the articles 8 and 12 , one slender spine on articles 10 and 11, a strong spine on article 13 and a strong spine on article 14 (but shorter than that on article 13); the spine on article 15 may have a wide variability (being absent, very short or strong in different specimens of the same Albanian population) (Fig. $2 \mathrm{M}, \mathrm{N}, \mathrm{O}$ ); antepenultimate article (Fig. 2L) with a long extension (slightly curved at the distal end) reaching the ultimate article.

\section{DISCUSSION}

The main anatomical features of the Albanian Neodiaptomus schmackeri (Poppe \& Richard, 1892) have been compared with the available descriptions of several populations of the wide distribution area of the species. The variability of body size and of some morphological characters is in line with the known species variability. In particular the spine on the article 15 of the male right antennula is confirmed to be one of the most variable feature of $N$. schmackeri. In fact, in the Albanian population, this spine can be absent or very small as in the Indian specimens described by Rajendran (1971), Bhattaracharya et al. (1990) and Ranga Reddy (1994), or strong as showed for the Thai specimens described by Lai and Fernando (1981), the Japanese specimens described by Semura et al (1986), the Russian ones by Borutzky et al. (1991), and those from Taiwan depicted by Young and Shih (2011). Among the Albanian specimens, we have observed this wide variability even in the population of the same lake and in the same date.

The high morphological variability of $N$. schmackeri does not allow to test if the species was simultaneously introduced in several lakes by fish stocking or introduced

Tab. 1. List of the sampled lakes in the Dumre plateau with the main environmental features. WGS1984 is the geographic coordinate system.

\begin{tabular}{|c|c|c|c|c|c|c|c|c|c|c|}
\hline Code & Name & Locality & $\begin{array}{l}\text { Latitude } \\
\qquad \mathrm{N}\end{array}$ & $\begin{array}{c}\text { Longitude } \\
\text { E }\end{array}$ & $\begin{array}{l}\text { Altitude } \\
\text { asl (m) }\end{array}$ & $\begin{array}{l}\text { Area } \\
\text { (ha) }\end{array}$ & $\begin{array}{c}\text { Perimeter } \\
\text { (m) }\end{array}$ & $\begin{array}{l}\text { Maximum } \\
\text { lenght (m) }\end{array}$ & $\begin{array}{l}\text { Maximum } \\
\text { width (m) }\end{array}$ & $\begin{array}{l}Z_{\max } \\
(\mathrm{m})\end{array}$ \\
\hline AL001* & Pernaska & Fierzë & $40^{\circ} 55^{\prime} 45^{\prime \prime}$ & $19^{\circ} 49^{\prime} 40^{\prime \prime}$ & 107 & 32.47 & 2200 & 780 & 500 & 2.0 \\
\hline AL002* & Dega & Hardhias & $40^{\circ} 55^{\prime} 32^{\prime \prime}$ & $19^{\circ} 50^{\prime} 25^{\prime \prime}$ & 110 & 30.86 & 3800 & 1600 & 300 & 12.0 \\
\hline AL003* & I Kuq & Hardhias & $40^{\circ} 56^{\prime} 38^{\prime \prime}$ & $19^{\circ} 51^{\prime} 14^{\prime \prime}$ & 138 & 6.84 & 1068 & 383 & 285 & 8.0 \\
\hline AL004 & Merhojes & Çepa & $40^{\circ} 56^{\prime} 39 ”$ & 19॰52’19”' & 108 & 65.50 & 3600 & 1420 & 730 & 42.0 \\
\hline AL005* & Dorbi & Çepa & $40^{\circ} 57^{\prime} 07^{\prime \prime}$ & $19^{\circ} 52^{\prime} 30^{\prime \prime}$ & 133 & 10.54 & 1315 & 444 & 338 & 2.0 \\
\hline AL006 & Belesh & Belsh & $40^{\circ} 58^{\prime} 47^{\prime \prime}$ & 19॰53’37’' & 148 & 29.60 & 2400 & 760 & 400 & 4.0 \\
\hline AL007 & Milosh & Gjyralë & $40^{\circ} 57^{\prime} 49 \prime$ & $19^{\circ} 58^{\prime} 50^{\prime \prime}$ & 70 & 5.70 & 868 & 287 & 276 & 32.0 \\
\hline AL008 & Bici & Gjyralë & $40^{\circ} 57^{\prime} 41^{\prime \prime}$ & $19^{\circ} 58^{\prime} 46^{\prime \prime}$ & 77 & 2.32 & 700 & 237 & 142 & 10.0 \\
\hline AL009 & Ulza & Gjyralë & $40^{\circ} 57^{\prime} 57^{\prime \prime}$ & $19^{\circ} 58^{\prime} 17^{\prime \prime}$ & 107 & 6.24 & 1525 & 485 & 117 & 2.3 \\
\hline AL010 & Katund & Gjyralë & $40^{\circ} 57^{\prime} 54^{\prime \prime}$ & $19^{\circ} 58^{\prime} 27^{\prime \prime}$ & 100 & 2.78 & 665 & 247 & 152 & 12.0 \\
\hline AL011 & Komnjec & Gjyralë & $40^{\circ} 57^{\prime} 58^{\prime \prime}$ & $19^{\circ} 57^{\prime} 26^{\prime \prime}$ & 136 & 1.83 & 495 & 150 & 147 & 12.0 \\
\hline AL012* & Cerrages & Cerrages & $40^{\circ} 55^{\prime} 27^{\prime \prime}$ & $19^{\circ} 48^{\prime} 59^{\prime \prime}$ & 115 & 24.13 & 2598 & 800 & 500 & 29.0 \\
\hline AL013* & Fierzë & Fierzë & $40^{\circ} 55^{\prime} 27^{\prime \prime}$ & 19॰51’20”' & 153 & 3.57 & 926 & 295 & 200 & 2.2 \\
\hline AL014* & Gjelaur & Belsh & $40^{\circ} 57^{\prime} 32^{\prime \prime}$ & $19^{\circ} 54^{\prime} 02^{\prime \prime}$ & 127 & 2.59 & 605 & 199 & 190 & 15.0 \\
\hline AL015* & Seferan & Belsh & $40^{\circ} 57^{\prime} 12^{\prime \prime}$ & 19॰54’12”' & 124 & 88.47 & 5900 & 2050 & 500 & 20.0 \\
\hline
\end{tabular}

*Refer to lakes hosting Neodiaptomus schmackeri. 


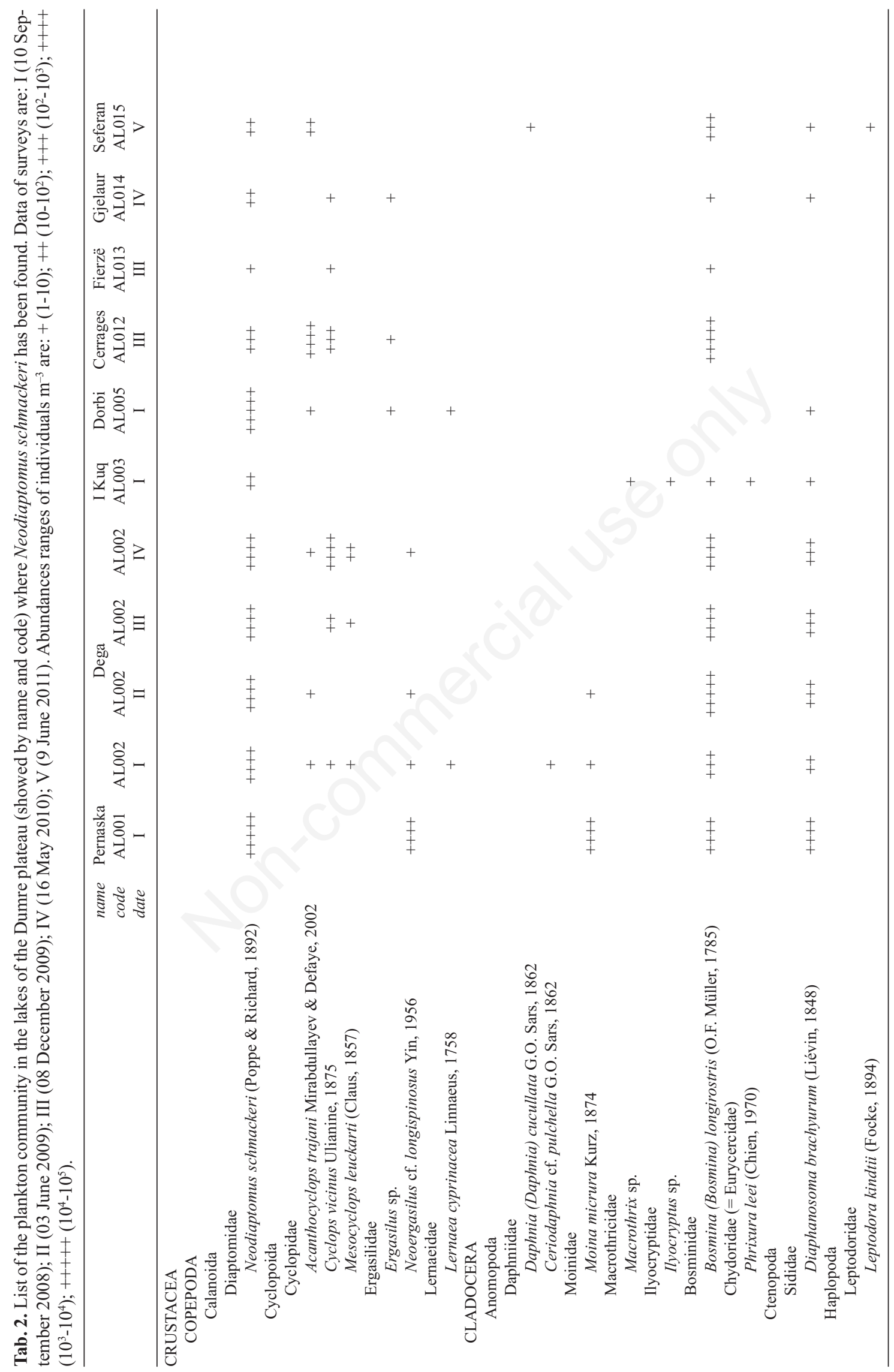




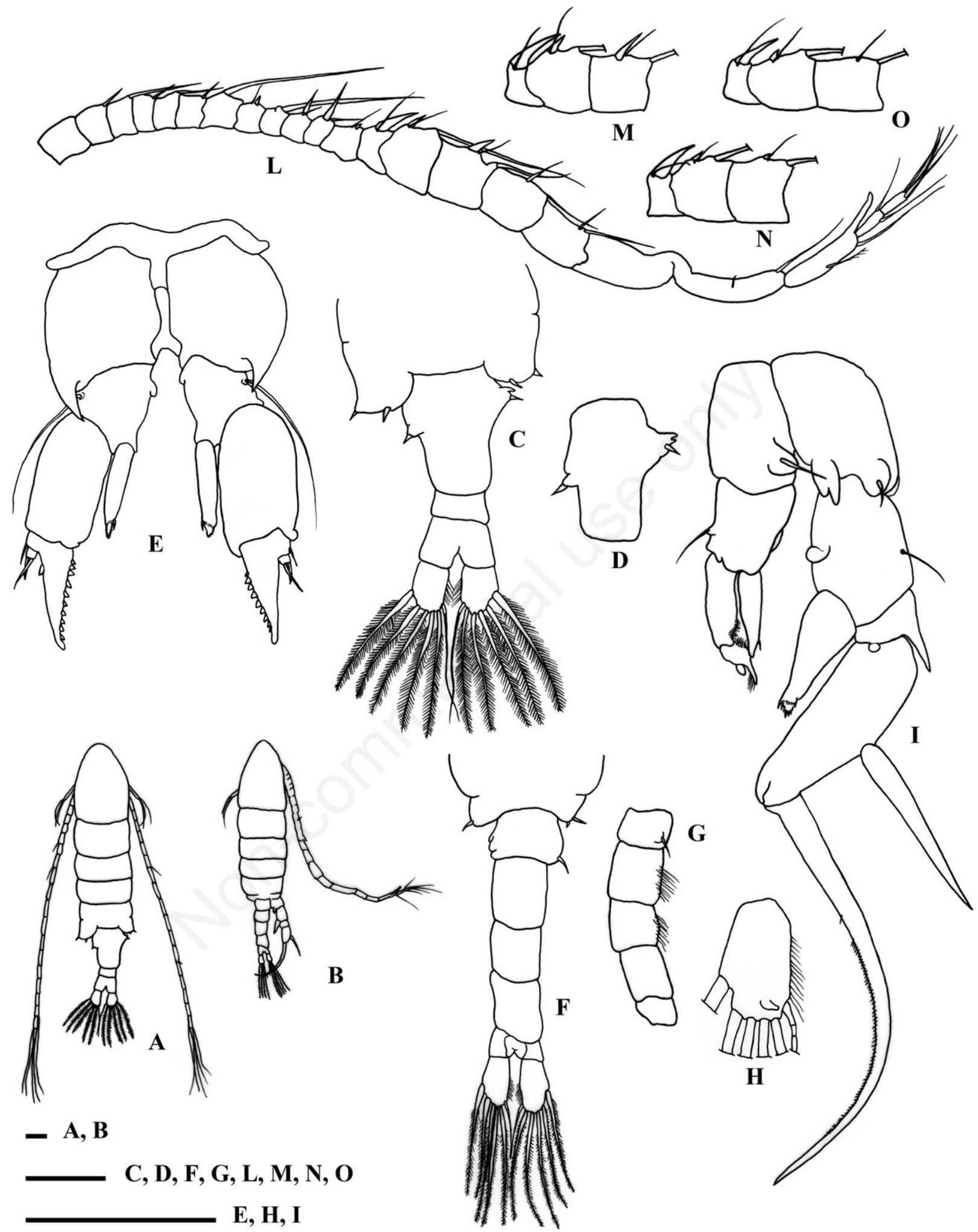

Fig. 2. Neodiaptomus schmackeri (Poppe and Richard, 1892), adult specimens (from the sample collected at lake Pernaska on 10 September 2008). Female: A, habitus, dorsal; C, urosome with the fourth and fifth thoracic segments, dorsal; D, genital somite of a different specimen, dorsal; E, fifth leg, posterior. Male: B, habitus, dorsal; F, urosome with the fourth and fifth thoracic segments, dorsal; G, urosome (in part), lateral; H, right furcal ramus, ventral; I, fifth leg, posterior; L, right antennula; M, N, O, segments 13-15 of the right antennula in three different specimens. Scale bars: $100 \mu \mathrm{m}$. 
in one lake (or few lakes) with subsequent dispersal across the other Dumre lakes. Geological studies exclude subsurface connections among the lakes of this area (Parise et al., 2008 and references therein), but surface connections are of course possible with flooding of lakes after abundant rains (coalescence of lakes) or man activities (fishery, agriculture, drainages).

$N$. schmackeri was abundant in the lakes where it was present, and dominant on the whole zooplankton community in the summer samples. Conversely, the lowest abundances of the species were recorded in winter (Tab. 2). On the Dumre plateau this species seemed to have preferred a group of very close shallow and eutrophic lakes in the central-western zone of the area (between the villages of Cerrages and Belsh). By the contrary, lake Merhojes (AL004), located in the middle of the above mentioned group of lakes, was found always without $N$. schmackeri in five different sampling dates. Lake Merhojes (42 m of maximum depth) is one of the deepest lakes of the Dumre plateau and it seems that it was not successfully colonized by the species. The aquatic environments in which we found N. schmackeri in Albania are shallow, permanent, eutrophic lakes (most of which addressed to aquaculture) with turbid waters, in accordance to what already documented, for instance, for the type locality in China (Poppe and Richard, 1892), for the reservoirs, fish ponds and permanent pools of Thailand (Lai and Fernando, 1981), Japan (Semura et al., 1986), Russia (Borutzky et al., 1991), and Taiwan (Young and Shi, 2011). Conversely the occurrence sites reported for India, are mainly turbid ephemeral pools rather than permanent lakes (Rajendran, 1971; Ranga Reddy, 1994).

The finding of N. schmackeri in Albania is noteworthy since it is the first record for Europe, and in general for the Western Palaearctic area, extraordinarily far (i.e., about 6000 kilometres) from the typical distribution area of the species that is South-Eastern Palaearctic-Oriental (Fig. 1A). Although no previous study is available on the zooplankton of the Dumre area, and considering the distribution of all the Neodiaptomus species, $N$. schmackeri can be identified as a non-indigenous copepod in Europe. Its introduction in the Dumre lakes could be related to the fish introduction occurred since 1960s in Albania from Asia for aquaculture purposes. Unfortunately, the dearth of previous studies on the plankton community of the Dumre lakes, prevents any comparison between the zooplanktonic communities before and after the aquaculture facilities were built. The presence (sometimes even dominance) of $N$. schmackeri in the zooplankton assemblages in half of the lakes visited, after more than 50 years of the presumed period of introduction, suggests a successful establishment of the species that might presently be more widespread in Albania (and in Europe) than we currently know.
The occurrence of the Asian diaptomid Neodiaptomus schmackeri in the lakes of the Dumre area testifies the detrimental effect of human activities, which might enhance the spreading of non-indigenous and invasive species. These represent a serious threat for the diversity and conservation of calanoids that, in some cases, are characterized by cryptic species with small distribution areas (Marrone et al., 2010, 2013). As a consequence, the risk that some species may disappear before they are even described is very high. For this reason investigations on the field are still necessary, especially those focusing on the less studied areas. The central-eastern area of the Mediterranean basin still presents several gaps of knowledge on the species distribution (Marrone, 2006), and recent studies (Alfonso and Belmonte, 2011, 2013) demonstrated that some areas, contrarily to what was previously assumed, are interested by very high species diversity.

Currently, we have preliminary limnological information on a scarce number of water bodies in the Dumre area (15 sites out of more than 100 water bodies). Albania, and most of the Balkans (especially in its southernmost part), are to date inadequately known lacking environmental researches and studies on its biodiversity assessment. This area therefore represents a potential target for further investigations aiming to outline the scenario of species' distribution and to evaluate the effects of the environmental stressors (comprising the presence of non indigenous species) on the biological communities.

\section{ACKNOWLEDGMENTS}

Vassilika Kalluci, Bilal Shkurtaj, Pretaq Truja and Petrit Kotori (University of Vlorë, Albania) are acknowledged for their assistance during the sampling campaigns and for the useful references. We thanks Sotir Mali (University of Elbasan, Albania) and Spase Schumka (University of Tirane, Albania) for providing us with information on sites. We are grateful to Lana Ong and Chad Walter (Smithsonian Institution, Washington, DC, USA) for the references on the species, and the deposit of voucher specimens from Dumre lakes in the Institution collection, respectively. Finally, we thank the two anonymous referees who contributed to improve a first draft of the manuscript.

\section{REFERENCES}

Alfonso G, Belmonte G, 2008. Expanding distribution of Boeckella triarticulata (Thomson, 1883) (Copepoda: Calanoida: Centropagidae) in Southern Italy. Aquat. Inv. 3:247-251.

Alfonso G, Belmonte G, 2011. Calanoida (Crustacea Copepoda) from the inland waters of Apulia (south-eastern Italy). J. Limnol. 70:57-68.

Alfonso G, Belmonte G, 2013. Neolovenula alluaudi (Guerne and Richard, 1890) (Calanoida: Diaptomidae: Paradiaptominae): first record in Italy and review of geographical distribution. J. Limnol. 72:251-261. 
Alonso M, 1996. [Crustacea, Branchiopoda]. [Book in Spanish]. Museo Nacional de Ciencias Naturales ed.: 486 pp.

Bhattacharya T, Saha RK, Dussart BH, 1990. On Neodiaptomus schmackeri (Poppe \& Richard, 1892) (Crustacea, Copepoda). Hydrobiologia 196:73-78.

Bauer ON, 1987. [Keys to the identification of parasites of freshwater fishes of the fauna of the USSR, vol. 3, Parasitic Metazoa. Pt. 2].[Book in Russian]. Nauka: 583 pp.

Borutzky EV, Stepanova LA, Kos MS, 1991. [Key of freshwater Calanoida of the USSR]. [Book in Russian]. Nauka: 504 pp.

Boxshall GA, Halsey SH, 2004. An introduction to copepod diversity. Ray Society Publ., London: 966 pp.

Brandorff GO, 2011. The copepod invader Skistodiaptomus pallidus (Herrick, 1879) (Crustacea, Copepoda, Diaptomidae) from North America in water bodies of Bremen, northern Germany. Aquat. Inv. 6:S1-S5.

Cobani M, 2010. National aquaculture sector overview. Albania. National Aquaculture Sector Overview Fact Sheets. Accessed on: 02 December 2013 Available from: http://www.fao. org/fishery/countrysector/naso_albania/en.

Cullaj A, Hasko A, Miho A, Schanz F, Brandl H, Bachofen R, 2005. The quality of Albanian natural waters and the human impact. Environ. Int. 31:133-146.

Dang NT, Ho TH, 2001. [Two new crustacean species of Diaptomidae found in the river section inside of the Phongnha cave, Quang Binh province, Vietnam]. [Article in Vietnamese]. Tap Chi Sinh Hoc 23:1-5.

Dhora D, 2010. [Regjistër i specieve të faunës së Shqipërisë]. [Book in Albanian]. Camaj-Pipa, Shkodër: 208 pp.

Dussart B, Defaye D, 2001. Introduction to the Copepoda. Backhuys Publishers, Leiden: 344 pp.

Dussart B, Defaye D, 2002. World directory of Crustacea Copepoda of inland waters. I. Calaniformes. Backhuys Publ., Leiden: $276 \mathrm{pp}$.

Einsle, U. 1993. [Crustacea Copepoda Calanoida und Cyclopoida. Süßwasserfauna von Mitteleuropa 8/4].[Book in German]. Gustav Fischer Verlag: 208 pp.

Ferrari I, Farabegoli A, Pugnetti A, Stella E, 1991. The occurrence of a Calanoid Australasian species, Boeckella triarticulata (Thomson), in fish ponds of Northern Italy. Verh. Int. Verein. Limnol. 24:2822-2827.

Ferrari I, Rossetti G, 2006. New records of the Centropagid Boeckella triarticulata (Thomson, 1883) (Copepoda: Calanoida) in Northern Italy: evidence of a successful invasion? Aquat. Inv. 1:219-222.

Gherardi F, 2007. Biological invaders in inland waters: profiles, distribution and threats. Springer: $733 \mathrm{pp}$.

Hanel L, Plesník J, Andreska J, Lusk S, Novák J, Plíštil J, 2011. Alien fishes in European waters. Bulletin Lampetra 7: 148-185.

Kiefer F, 1978. [Das Zooplankton der Binnengewässer. Freilebende Copepoda. Die Binnengewässer. 2]. [Book in German]. E. Schweizerbartische Verlagbuchhandlung: 343 pp.

Lai HC, Fernando CH, 1981. The freshwater Calanoida (Crustacea: Copepoda) of Thailand. Hydrobiologia 76:161-178.

Margaritora FG, 1985. [Cladocera].[Book in Italian]. Calderini: 389 pp.

Marrone F, 2006. The microcrustacean fauna of Sicily and the Central Mediterranenan Sea area-current knowledge and gap to be filled. Pol. J. Ecol. 54:681-685.
Marrone F, Lo Brutto S, Arculeo M, 2010. Molecular evidence for the presence of cryptic evolutionary lineages in the freshwater copepod genus Hemidiaptomus G.O. Sars, 1903 (Calanoida, Diaptomidae). Hydrobiologia 644: 115-125.

Marrone F, Lo Brutto S, Hundsdoerfer AK, Arculeo M, 2013. Overlooked cryptic endemism in copepods: Systematics and natural history of the calanoid subgenus Occidodiaptomus Borutzky 1991 (Copepoda, Calanoida, Diaptomidae). Mol. Phylogenet. Evol. 66:190-202.

Mirabdullayev IM, Defaye D, 2002. On the taxonomy of the Acanthocyclops robustus species complex (Copepoda, Cyclopidae). 1. Acanthocyclops robustus (GO Sars, 1863) and Acanthocyclops trajani n.sp. Selevinia 1-4:7-20.

Parise M, Qiriazi P, Sala S, 2008. Evaporite karst of Albania: main features and cases of environmental degradation. Environ. Geol. 53:967-974.

Peja N, Smajlaj R, Faja A, 2002. [Përcaktuesi i peshqve].[Book in Albanian]. Eslebor: 104 p.

Poppe SA, Richard J, 1892. [Description du Diaptomus schmackeri, n. sp., recueilli par M. Schmaker dans le lac Tahoo (Chine)]. [Article in French]. Bull. soc. Zool. Fr. 17: 149-151.

Proongkiat K, Sanoamuang LA, 2008. Description of Neodiaptomus siamensis, a New Diaptomid Copepod (Copepoda, Calanoida) from Temporary Pools in Northern Thailand. Crustaceana 81:177-189.

Qiriazi P, Sala S, 2000. Environmental problems of Albania, p. 13-30. In: M.F. Buchroithner (ed.) Remote sensing for environmental data in Albania: a strategy for integrated management. Kluwer.

Rajendran M, 1971. Redescription of the freshwater calanoid Neodiaptomus schmackeri and comments on interrelationships and distributional pattern of the schmackeri group of species. Crustaceana 21:92-100.

Ranga Reddy Y, 1994. Copepoda: Calanoida: Diaptomidae. Key to the genera Heliodiaptomus, Allodiaptomus, Neodiaptomus, Phyllodiaptomus, Eodiaptomus, Arctodiaptomus and Sinodiaptomus. SPB Academic: $221 \mathrm{pp}$.

Ranga Reddy Y, 2013. Neodiaptomus prateek n. sp., a new freshwater copepod from Assam, India, with critical review of generic assignment of Neodiaptomus spp. and a note on diaptomid species richness (Calanoida: Diaptomidae). J. Crustacean. Biol. 33:849-865.

Ranga Reddy Y, Subba Reddy PV, 1992. A note on the synonymy of some Neodiaptomus spp. (Copepoda, Calanoida) of the Indian subcontinent. Hydrobiologia 231:125-129.

Riccardi N, Giussani G, 2007. The relevance of life-history traits in the estabilishment of the invader Eudiaptomus gracilis and exctinction of Eudiaptomus padanus in Lake Candia (Northern Italy): evidence for competitive e exclusion? Aquat. Ecol. 41:243-254.

Riccardi N, Rossetti G, 2007. Eudiaptomus gracilis in Italy: how, where and why. J. Limnol. 66:64-69.

Rossetti G, Dussart B, Viaroli P, 1996. Finding of the calanoid Eudiaptomus gracilis (Sars) in perifluvial environments of the Po River. Mem. Ist. Ital. Idrobiol. 54:51-59.

Roy T, 1999. Crustacea: Copepoda: Calanoida \& Cyclopoida, p. 285-313. In: Fauna of West Bengal, part 10. Zoological Survey of India, Calcutta.

Sanoamuang L, Athibai S, 2002. A new species of Neodiapto- 
mus (Copepoda, Diaptomidae) from temporary waters in northeast Thailand. Hydrobiologia 489:71-82.

Semura H, Goto E, Yamamoto K, Kawashima T, 1986. [New record of a freshwater copepod Neodiaptomus schmackeri (Calanoida: Diaptomidae) from Kata-no-uchi, Shimane prefecture, western Japan].[Article in Japanese]. Bull. Plankton Soc. Jap. 33:125-131.

Shehu M, Serravalle F, Alfonso G, Moscatello G, Belmonte G, 2009. The alpine Lake Gistova (Mount Gramos, AlbaniaGreece border) biodiversity of an isolated microcosm. Thalassia Salentina 32:53-62.

Shumka S, Paparisto A, Grazhdani S, 2008. Identification of non-native freshwater fishes in Albania and assessment of their potential threats to the national biological freshwater diversity, p. 1-6. Proceedings $3^{\text {rd }}$ Int. Scientific Conf. on Water Observation and Information Systems for Decision
Support. Balkan Institute for Water and Environment, Ohrid, Republic of Macedonia.

Visconti A, Manca M, 2010. The invasive appearance of Eudiaptomus gracilis (G.O. Sars 1863) in Lago Maggiore. J. Limnol. 69:353-357.

Walter, TC, 2013. Neodiaptomus Kiefer, 1932. In: T.C. Walter and G. Boxshall (eds.), World of Copepods database. Accessed on: 13 November 2013. Available from: World Register of Marine Species at http://www.marinespecies.org/aphia.php? $\mathrm{p}=$ taxdetails\&id $=347568$

Young SS, Shih CT, 2011. Freshwater calanoids (Copepoda, Calanoida) of Taiwan with some comments on the morphology of Neutrodiaptomus tumidus Kiefer, 1937 observed by SEM. In: D. Defaye, E. Suárez-Morales and J.C. von Vaupel Klein (eds.), Studies on freshwater Copepoda: a volume in honour of Bernard Dussart. Crustaceana Monographs 16:545-566. 